\title{
Wybrane zagadnienia z zakresu antykorozji stalowych konstrukcji spawanych na podstawie niemieckich przepisów ZTV-ING i VGB/BAW
}

\author{
Selected requirements regarding corrosion protection \\ for welded steel constructions regarding \\ German requirements ZTV-ING and VGB/BAW
}

\section{Streszczenie}

W referacie przedstawiono przykłady wymagań rynku niemieckiego dla wytwarzania konstrukcji stalowych wg niemieckich przepisów ZTV-ING. Przedstawiono przykłady wymagań dla materiałów i wykonawstwa konstrukcji. Szczególną uwagę poświęcono wymaganiom dla zabezpieczenia antykorozyjnego zawartych w części 4 rozdział 3.

Referat przedstawia również przykłady wymagań z zakresu antykorozji konstrukcji morskich wież wiatrowych oraz komponentów farm wiatrowych zawartych w projekcie dokumentu VGB/BAW.

Szczególną uwagę zwrócono na bezwzględną konieczność spełnienia wymagań w zakresie zabezpieczeń antykorozyjnych konstrukcji oraz kwalifikacji i kompetencji personelu antykorozji. Referat odnosi się również do możliwości spełnienia tych wymagań na rynku polskim.

Słowa kluczowe: zabezpieczenie antykorozyjne; konstrukcje stalowe; personel antykorozji

\begin{abstract}
This lecture discusses examples for requirements on the German market for production of steel constructions following ZTV-ING. There are examples for material selection and requirements for construction. A special role is taken for requirements regarding corrosion protection in part 4 chapter 3 .

This lecture also discusses examples for corrosion protection for offshore wind power towers and components according to VGB/BAW.

There is a special regard for the muss of fulfilling the requirements for corrosion protection and the qualification and competence of the personnel for corrosion protection. This lecture also discusses the possibility for fulfilling this requirements on the Polish market.
\end{abstract}

Keywords: corrosion protection; steel constructions; corrosion protection personnel

\section{Wstęp}

Jedną z najważniejszych cech konstrukcji inżynierskich jest ich trwałość. Konstrukcje powinny być tak zaprojektowane i wykonane, aby w przyjętym okresie użytkowania zapewniona była zdolność do ich użytkowania przy zachowaniu cech wytrzymałościowych i eksploatacyjnych obiektu.

Materiały użyte do budowy powinny zapewnić trwałość odpowiednio do przyjętych okresów użytkowania. Przy ich doborze powinny być brane pod uwagę nie tylko cechy fizyczne i mechaniczne, ale również ich odporność na oddziaływanie środowiska, w którym konstrukcja będzie użytkowana.
Zabezpieczenie konstrukcji stalowych powinno być zrealizowane przez ochronę konstrukcyjną (właściwe zaprojektowanie konstrukcji - m.in. brak: miejsc trudnodostępnych, miejsc, w których może gromadzić się woda, karbów, nieszczelnych połączeń stykowych), materiałowo-strukturalną (konstrukcje nie powinny zawierać materiałów o różnym potencjale elektrochemicznym) i powierzchniową (powłoki malarskie, metalizacyjne i metalizacyjno-malarskie). Powłoki antykorozyjne powinny być dostosowane do rodzaju materiału, z którego konstrukcja jest wykonana i środowiska,

Mgr inż. Martin Czysch - GSI-SLV Duisburg; mgr inż. Jerzy Kozłowski - SLV-GSI Polska Sp. z 0.0.; mgr inż. Jakub Kozłowski - Politechnika Częstochowska.

Autor korespondencyjny/Corresponding author: jerzy.kozlowski@slv-polska.pl 
w którym pracuje. Niezmiernie ważnym jest również sposób prowadzenia procesu nakładania powłok antykorozyjnych, począwszy od zapewnienia właściwych warunków środowiskowych, poprzez monitorowanie właściwego przebiegu nakładania powłok, a na badaniach wykonanych powłok kończąc. By proces specjalny, jakim jest proces antykorozji był skuteczny, musi być prowadzony i nadzorowany przez kompetentny personel.

\section{Wymagania dla konstrukcji stalowych funkcjonujące na rynku niemieckim}

W zakresie stalowych i aluminiowych konstrukcji budowlanych obowiązują wymagania zawarte w EN 1090-1,-2,-3 [1], której część 1 jest zharmonizowana z Rozporządzeniem Parlamentu Europejskiego i Rady (UE) 305/2011 [2]. W zakresie konstrukcji drogowych obiektów inżynierskich np. mosty, infrastruktura drogowa, obowiązują również wymagania przepisu: „Dodatkowe warunki techniczne umów i wytyczne dla konstrukcji inżynierskich (ZTV-ING)" [3] część 4, „Konstrukcje stalowe i kompozytowe". W dokumencie tym, w rozdziale 1 zawarto wymagania w stosunku do wykonania konstrukcji stalowych. Natomiast w rozdziale 3 "Ochrona antykorozyjna konstrukcji stalowych" zawarte są wymagania w zakresie ochrony antykorozyjnej. Znajomość wymagań ZTV-ING jest ważna dla wytwórców polskich wykonujących konstrukcje inżynierskie dla klientów niemieckich.

W ustaleniach kontaktowych zawarte są często oprócz wymagań normy EN 1090 [1] również wymagania ZTV-ING [3].

\section{Wykonanie konstrukcji z uwzględnieniem ZTV-ING}

\section{Wymagania w odniesieniu do wykonawcy}

Wymaganiem jest, że wykonawca konstrukcji musi posiadać certyfikat zakładowej kontroli produkcji wg EN 1090-1 [1] oraz świadectwo spawalnicze wg EN 1090-2 [1] adekwatne dla klasy wykonania konstrukcji EXC. W przypadku konstrukcji klasy EXC3 nadzór spawalniczy musi posiadać pełną wiedzę techniczną - poziom C wg normy EN ISO 14731 [4].

\section{Wymagania dla materiałów}

Dopuszczone do zastosowania są materiały o klasach wytrzymałości S235, S355, S460. Materiały muszą być zgodne z normami EN 10025-1,-5 [5], EN 10210 [6], EN 10219 [7]. W przypadku profili zamkniętych wg EN 10210 [6], o ściankach o grubości $\geq 30 \mathrm{~mm}$ wymaganiem jest stan po wyżarzaniu normalizującym (NH lub NLH). Dla konstrukcji nośnych mostów nie dopuszcza się stali o zagwarantowanej udarności w temperaturze +20 i $0{ }^{\circ} \mathrm{C}$ (JR i J0). Częstym wymaganiem jest również określenie własności w kierunku prostopadłym do powierzchni (Z15, Z25, Z35). Właściwości stali muszą być potwierdzone świadectwem odbioru 3.2 wg EN 10204 [8] zatwierdzonym przez uznaną jednostkę.

Dla konstrukcji innych niż nośne, wymagane są świadectwa zgodnie z normą EN 1090-2 [1]. Świadectwa materiałowe muszą być przedstawione przed przystąpieniem do wytwarzania konstrukcji. ZTV-ING [3] określa informacje, jakie świadectwa powinny zawierać, a to m.in. skład chemiczny (15 pierwiastków C, Si, Mn, P, S, Al, N, Cr, Cu, Mo, Ni, Nb, Ti, V, B), wartość równoważnika węgla CEV oraz potwierdzenie spełnienia wymagań próby wg SEP 1390 [9] dla materiałów do S355 i grubości od $30 \mathrm{~mm}$. Funkcjonujące na polskim rynku świadectwa najczęściej zawierają określenia składu chemicznego tylko dla 14 pierwiastków, natomiast próba SEP 1390 [9] czy próba "Z" wg EN 10164 [10], wykonywane są jako próby dodatkowe, które należy uwzględnić w zamówieniu stali. Dlatego ważnym jest by w zamówieniach stali określić wszystkie niezbędne wymagania.

W przywołanych przepisach określone zostały wymagania w zakresie poziomu jakości dla złączy spawanych, badań wykonanych konstrukcji. W zakresie nadzoru nad wykonaniem konstrukcji oraz jej zabezpieczeniem antykorozyjnym wymagany jest dodatkowy zewnętrzny nadzór wskazany przez zamawiającego.

Powyżej przedstawiono tylko niektóre wymagania w zakresie wykonania, zawarte w ZTV-ING [3]. Wykonawca konstrukcji musi przeanalizować sposób spełnienia wszystkich wymagań przed podjęciem decyzji o realizacji zlecenia.

\section{Wymagania w zakresie projektowania \\ i wykonania zabezpieczenia antykorozyjnego}

Poniżej przedstawiono niektóre z wymagań ZTV-ING [3] w zakresie projektowania i wykonania zabezpieczenia antykorozyjnego. Projektowanie konstrukcji przeznaczonych do cynkowania ogniowego oraz proces cynkowania muszą uwzględniać wymagania normy EN ISO 14713 [11], oraz przepisów DASt 022 [12].

W przypadku zabezpieczenia antykorozyjnego poprzez malowanie, wymagany jest stopień przygotowania P3 wg EN ISO 8501-3 [13] dla krawędzi, spoin i innych obszarów powierzchni stalowych zawierających wady powierzchni. Dla nierówności lica spoin dopuszczalny jest stopień P2. Możliwe jest zastosowanie potrójnego fazowania krawędzi zamiast zaokrąglenia.

Powierzchnie do malowania należy przygotować metodą strumieniowo ścierną z zastosowaniem ścierniwa ostrokątnego. Wymagany stopień przygotowania podłoża (również powierzchni spoin) to, co najmniej Sa 21/2 zgodnie z EN ISO 12944-4 [14]. Uzyskany profil powierzchni po obróbce strumieniowo ściernej musi być, co najmniej „pośredni" (G) zgodnie z EN ISO 8503-1 i -2 [15].

Jeżeli elementy zostały pokryte powłoką ochrony czasowej, to istniejącą powłokę należy usunąć przed nakładaniem powłoki podkładowej przy pomocy suchej obróbki strumieniowo ściernej. Niedozwolone jest również spawanie elementów pokrytych powłoką ochrony czasowej.

Ochronę krawędzi półek, kołnierzy, usztywnień, śrub i spoin (nie dotyczy złączy wykonywanych na budowie) wykonać należy po nałożeniu powłoki podkładowej. W powłokach podkładowych z pyłem cynkowym ochrona krawędzi musi być wykonana farbą z fosforanem cynku. Jeśli aplikacja farb dokonywana jest przez natryskiwanie, obszary, takie jak narożniki, śruby i łby nitów lub inne trudno dostępne miejsca należy wyprawić pędzlem przed albo po aplikacji. Nie dopuszcza się aplikacji powłoki gruntowej wałkiem. Przy malowaniu elementów na warsztacie, dla obszarów spoin wykonywanych na budowie należy:

- obszary spawania zakleić $50 \mathrm{~mm}$ od krawędzi przyszłej spoiny,

- podkład gruntowy o nominalnej grubości malować aż do zaklejonego miejsca,

- pierwszą międzywarstwę malować do 250 mm od krawędzi spoiny,

- każdą następną warstwę malować 50 mm od warstwy poprzedniej.

\section{Wymagania w stosunku do personelu antykorozji}

Prace antykorozyjne muszą być wykonywane przez osoby, które posiadają niezbędne kwalifikacje (dotyczy to również kierownika budowy). Już na etapie ofertowania 
wymagane jest przedstawienie odpowiednich świadectw potwierdzających. Wymaganym jest, by brygadzista bezpośrednio nadzorujący prace antykorozyjne był stale obecny $w$ miejscu pracy podczas wykonywania robót antykorozyjnych. Szczególnie ważne wymaganie przy pracach prowadzonych w cyklu 2 lub 3 zmianowym. Kwalifikacje brygadzisty muszą być potwierdzone egzaminem. Tym egzaminem jest:

- dla oferentów krajowych świadectwo szkolenia Rady Doradczej Federalnego Stowarzyszenia ochrony antykorozyjnej e.V. (KORSchein);

- dla oferentów zagranicznych równorzędny dowód kwalifikacji (wg wiedzy autorów referatu akceptowalne jest, dla oferentów z Polski, ukończenie 3 tygodniowego kursu „Projektowanie i nadzór nad wykonaniem zabezpieczeń antykorozyjnych na konstrukcjach stalowych" prowadzonych przez Instytut Badawczy Dróg i Mostów).

Po 3 latach od uzyskania ww. kwalifikacji koniecznym jest powtórne szkolenie zgodnie z wymogami Rady Doradczej Edukacji.

Warunki dopuszczenia do egzaminu KORSchein, jakie musi spełnić kandydat to:

- ukończenie, co najmniej dwuletniego szkolenia zawodowego, kierunkowego i udowodnienie, co najmniej dwuletniego, praktycznego doświadczenia zawodowego w dziedzinie ochrony antykorozyjnej konstrukcji stalowych;

- wykształcenie mistrza o odpowiednim wykształceniu technicznym i udowodnienie, co najmniej rocznego, praktycznego doświadczenia zawodowego w dziedzinie ochrony antykorozyjnej konstrukcji stalowych;

- ukończenie średniej szkoły technicznej i udowodnienie, co najmniej rocznego, praktycznego doświadczenia zawodowego w dziedzinie ochrony antykorozyjnej konstrukcji stalowych;

- osoby, które nie potrafią udowodnić wyszkolenia mogą być dopuszczone do egzaminu, jeśli udowodnią dziesięcioletnie praktyczne doświadczenie zawodowe $\mathrm{w}$ dziedzinie ochrony antykorozyjnej konstrukcji stalowych;

- stopień inżyniera i udowodnienie, co najmniej rocznego, praktycznego doświadczenia zawodowego w dziedzinie ochrony antykorozyjnej konstrukcji stalowych.

Egzamin przeprowadzany jest po ukończeniu 3 tygodniowego kursu (120 jednostek lekcyjnych). Podczas egzaminu trwającego 3 godziny sprawdzana jest znajomość z następujących tematów:

- podstawowe przepisy i regulacje,

- korozja i ochrona antykorozyjna stali i cynku,

- systemy powłokowe / systemy ochrony przed korozją,

- przygotowanie powierzchni,

- aplikacja materiałów powłokowych,

- sprzęt i urządzenia do przygotowania powierzchni,

- sprzęt i urządzenia do aplikacji,

- zapewnienie jakości,

- ochrona betonu i naprawa konstrukcji mostowych,

- zastosowanie rusztowań w pracach związanych z ochroną przed korozją,

- wyliczenia i kalkulacje,

- zarządzanie personelem,

- bezpieczeństwo pracy i ochrona środowiska.

Za pozytywny wynik egzaminu uznaje się uzyskanie minimum 50\% możliwych do zdobycia punktów.

Jak wynika z przedstawionych warunków, wymagania kwalifikacyjne dla brygadzistów bezpośrednio nadzorujących prace antykorozyjne postawione są bardzo wysoko. Warunki te i możliwości ich spełnienia należy uwzględnić podczas przeglądu wymagań kontraktu.

\section{Wykonanie konstrukcji przybrzeżnych turbin wiatrowych z uwzględnieniem wymagań VGB/BAW}

Wzrost ilości instalowanych turbin wiatrowych skłania do podjęcia działań mających na celu obniżenie kosztów instalacji i obsługi oraz zwiększenie bezpieczeństwa pracy turbin. W tym celu VGB PowerTech e.V. i Federalna Instytucja Budowli Wodnych (BAW) postanowili wspólnie stworzyć VGB/BAW [16] - standard do ochrony antykorozyjnej przybrzeżnych turbin wiatrowych i komponentów farm wiatrowych. Celem jego jest obniżenie wysokich kosztów inwestycji w morskie elektrownie wiatrowe oraz zapewnienie ochrony konstrukcji przed korozją, przez co najmniej 25 lat. Założeniem jest, stosowanie systemów antykorozyjnych pozwalających na uniknięcie kosztownych napraw na morzu.

Wprowadzenie wymagań VGB/BAW [16] planowane jest w roku 2018.

\section{Wymagania w zakresie projektowania i wykonania zabezpieczenia antykorozyjnego wg VGB/BAW [16]}

Oprócz wymagań ZTV-ING [3] przedstawionych w p. 2 niniejszego referatu, przepis VGB/BAW [16] przewiduje wymagania dodatkowe. I tak dla procesów natryskiwania cieplnego należy przestrzegać wymagań norm EN ISO 12690 [17], EN ISO 14918 [18], EN ISO 14923 [19]. Mogą być tylko stosowane systemy antykorozyjne zatwierdzone przez Federalny Instytut Budowli Wodnych (BAW). Czyszczenie konstrukcji za pomocą obróbki strumieniowo-ściernej może być prowadzone tylko w zamkniętych pomieszczeniach z klimatyzacją. Warunki klimatyczne powinny być monitorowane w sposób ciągły, od początku czyszczenia aż do zakończenia nakładania pierwszej warstwy powłoki. Określone zostały minimalne wymagane warunki przy pracy na warsztacie oraz (pod namiotem):

- temperatura powietrza $+10 \div+30^{\circ} \mathrm{C}$ (warsztat/namiot);

- temperatura obiektu $+10 \div+25{ }^{\circ} \mathrm{C}$ oraz $5{ }^{\circ} \mathrm{C}$ powyżej punktu rosy (warsztat/namiot);

- wilgotność względna $\leq 65 \%$ warsztat oraz $\leq 40 \%$ w przypadku obróbki pod namiotem.

Należy w tym zakresie zwrócić uwagę na zaostrzenie wymagań w zakresie wilgotności powietrza i różnicy temperatury względem temperatury punktu rosy.

W stosunku do przygotowania powierzchni wymagane jest, by było ono sprawdzone wg EN ISO 12994-4 [14]. Koniecznym jest osiągnięcie przynajmniej stopnia BSa21/2. Czystość powierzchni należy sprawdzić metodą taśmy samoprzylepnej wg DIN Fachbericht 28 [20]. Przy czym nie może być przekroczona wartość 2 dla ilości i wielkości wg EN ISO 8502-3 [21]. Jeżeli stopień czystości nie jest osiągnięty musi być wykonane ponowne czyszczenie. Przygotowana i oczyszczona powierzchnia powinna być również wolna od zanieczyszczeń rozpuszczalnych w wodzie. Pomiar należy wykonać bezpośrednio przed malowaniem, metodą tamponową wg DIN Fachbericht 28 [20] lub metodą Bresl'a wg EN ISO 8502-6 [21], przy czym zastosowanie tej metody musi być uzgodnione ze zleceniodawcą. Wartość graniczna koncentracji zanieczyszczeń, na powierzchni badanej nie może przekroczyć $50 \mathrm{mg} / \mathrm{m}^{2}$ anionów lub $80 \mathrm{mg} / \mathrm{m}^{2}$ soli. Jeśli w kartach technicznych farb wymagana jest wartość niższa, to powinna być ona osiągnięta.

Wymagania dla warunków klimatycznych podczas aplikacji farb są analogicznie jak dla obróbki strumieniowościernej. Tu również należy pamiętać o zaostrzonych wymaganiach w stosunku do wilgotności i temperatury.

Oczywistym wymaganiem jest konieczność wyprawienia pędzlem wszystkich kątów, krawędzi, szczelin, otworów 
na śruby, nierównych spoin, nitów i miejsc o niedostatecznym dostępie. W trakcie czyszczenia i nakładania powłok wykonawca musi wykonać płyty próbne dla każdej strefy konstrukcji i dla każdego rejonu inspekcyjnego.

Pomiar grubości pojedynczej warstwy i całego systemu wykonuje się wg ISO 19840 [22] z kalibracją na gładkiej powierzchni. Pomiar wykonuje się równomiernie na całej grubości malowanej (min. 4 punkty pomiarowe $/ \mathrm{m}^{2}$; przy powierzchniach mniejszych niż $6 \mathrm{~m}^{2}$ - przynajmniej 25 pomiarów). Podane grubości warstw są zdefiniowane jako nominalne.

Dla każdej pojedynczej powłoki i dla całego systemu dopuszcza się max. 2-krotne przegrubienie. Wymagane jest również przeprowadzenie kontroli szczelności powłoki wg DIN 55670 [23] na całej powierzchni, za pomocą wysokiego napięcia, po całkowitym utwardzeniu powłoki. Na wykonanych płytach próbnych należy również wykonać badanie przyczepności powłok dla każdego obszaru testowego. Badanie przyczepności w strefach 1 i 2 wykonuje się wg EN ISO 4624 [24] i EN ISO 16276 [25] cz. 1 Próba odrywowa i cz. 2 Nacięcie krzyżowe. Przy czym wymaganiem dla próby odrywowej jest: - ilość stempli na każdej płycie - 5;

- wymagania min. - $8 \mathrm{MPa}$ w strefie 1 i $5 \mathrm{MPa}$ w strefie 2;
- przełomy z rozerwaniem między powłoką i stalą są niedopuszczalne (A/B);

- przy rozerwaniach mieszanych, max. dopuszcza się 10\% rozerwania $A / B$.

Wymaganiem dla nacięcia krzyżowego jest stopień $\leq 1$ wg EN ISO 16276-2 [25].

\section{Wymagania w zakresie personelu antykorozji}

VGB/BAW wprowadza wymaganie stałej obecności w miejscu pracy, podczas wykonywania prac antykorozyjnych, brygadzisty ze świadectwem KORSchein wg ZTV-ING [3]. Natomiast pracownicy wykonujący prace antykorozyjne muszą posiadać odpowiednie kwalifikacje i wieloletnie doświadczenie w zakresie ochrony przed korozją, udowodnione wg DIN EN ISO 12944-7 [14].

W ramach samokontroli zleceniobiorca musi, dla prac przeciwkorozyjnych na budowie, zatrudnić inspektora z certyfikatem DIN CERTCO stopień C lub porównywalnym (np. FROSIO 3 lub NACE 3). Inspektor ten ma być odpowiedzialny za czynności zapewnienia jakości, dotrzymania istotnych przepisów BHP, ochrony środowiska i opracowywania dokumentacji.

\section{Podsumowanie}

Mając na uwadze przywołane uregulowania ZTV-ING [3] oraz VGB/BAW [16] należy szczególną uwagę zwrócić na konieczność zapoznania się z tymi wymaganiami przed podpisaniem kontraktu. Niezmiernie ważne jest wymaganie w stosunku do kompetencji i kwalifikacji personelu antykorozji. Biorąc pod uwagę dostępność polskojęzycznych kursów spełniających przywołane w referacie wymagania oraz czas ich trwania (kurs IBDiM organizowany jest w sekwencji 3x1 tydzień i jest rozciągnięty w czasie kilku miesięcy natomiast kurs FROSIO wg NS 476, organizowany przez GSI-SLV Duisburg i SLV-GSI Polska trwa 2 tygodnie i na chwilę obecną uruchamiane są tylko 3 edycje w ciągu roku), decyzja o szkoleniu pracowników musi zapaść odpowiednio wcześniej. Jeśli w planach działalności firmy, uwzględnia się wykonawstwo konstrukcji na rynek niemiecki, należy się liczyć również z koniecznością spełnienia wymagań ZTV-ING [3] czy VGB/BAW. Należy wówczas zaplanować sposób spełnienia wymagań w stosunku do możliwości technicznych wytworzenia konstrukcji oraz wymagań w stosunku do personelu antykorozji, a w przypadku braków podjąć decyzję o jego szkoleniu. Oczywiście możliwe jest również zaangażowanie personelu zewnętrznego, trzeba w takim wypadku uwzględnić dodatkowy koszt z tym związany, jak również jego dostępność na rynku.

Jeśli świadomość konieczności spełnienia wymagań pojawi się dopiero w chwili uzgadniania warunków kontraktu - to jest to najczęściej świadomość spóźniona.

\section{Literatura}

[1] EN 1090-1,-2,-3+A1:2012 Wykonanie konstrukcji stalowych i aluminiowych Część 1: Zasady oceny zgodności elementów konstrukcyjnych; Część 2: Wymagania techniczne dotyczące konstrukcji stalowych; Część 3: Wymagania techniczne dotyczące wykonania konstrukcji aluminiowych.

[2] Rozporządzenie Parlamentu Europejskiego i Rady (UE) nr 305/2011 z dnia 9 marca 2011

[3] ZTV-ING:2012 - Dodatkowe warunki techniczne umów i wytyczne dla konstrukcji inżynierskich.

[4] EN ISO 14731:2006 Nadzorowanie spawania. Zadania i odpowiedzialność

[5] EN 10025:2004 Wyroby walcowane na gorąco ze stali konstrukcyjnych.

[6] EN 10210:2006 Kształtowniki zamknięte wykonane na gorąco ze stali konstrukcyjnych niestopowych i drobnoziarnistych.

[7] EN 10219:2006 Kształtowniki zamknięte ze szwem wykonane na zimno ze stali konstrukcyjnych niestopowych I drobnoziarnistych.

[8] EN 10164:2004 Wyroby stalowe o podwyższonych własnościach plastycznych w kierunku prostopadłym do powierzchni. Warunki techniczne dostawy.

[9] EN 10204:2004 Wyroby metalowe. Rodzaje dokumentów kontroli.

[10] SEP 1390 próba spawalności poprzez zginanie próbki napawanej.

[11] EN 14713:2010 Powłoki cynkowe - Wytyczne i zalecenia dotyczące ochrony przed korozją konstrukcji ze stopów żelaza.

[12] DASt 022 Deutscher Ausschuß für Stahlbau. (Cynkowanie ogniowe nośnych elementów stalowych).

[13] EN 8501-3:2007 Przygotowanie podłoży stalowych przed nakładaniem farb i podobnych produktów - Wzrokowa ocena czystości powierzchni. Część 3: Stopnie przygotowania spoin, krawędzi i innych obszarów z wadami powierzchni.
[14] EN ISO12944-1 $\div 8: 1998$ Farby i lakiery - Ochrona przed korozją konstrukcji stalowych za pomocą ochronnych systemów malarskich.

[15] EN ISO 8503-1 i -2:1995 Przygotowanie podłoży stalowych przed nakładaniem farb i podobnych produktów. Charakterystyki chropowatości powierzchni podłoży stalowych po obróbce strumieniowo-ściernej.

[16] VGB/BAW - Standard ochrony antykorozyjnej morskich turbin wiatrowych i komponentów farm wiatrowych.

[17] EN ISO 12690:2010 Powłoki metalowe i inne nieorganiczne. Nadzór nad natryskiwaniem cieplnym. Obowiązki i odpowiedzialność.

[18] EN ISO 14918:1998 Natryskiwanie cieplne. Egzamin dla metalizatorów.

[19] EN ISO 14923:2003 Natryskiwanie cieplne. Charakterystyka i badanie powłok natryskiwanych cieplnie.

[20] DIN Fachbericht 28 (Raport techniczny 28).

[21] EN ISO 8502 Przygotowanie podłoży stalowych przed nakładaniem farb i podobnych produktów - Badania służące do oceny czystości powierzchni.

[22] ISO 19840:2004 Farby i lakiery. Ochrona przed korozja konstrukcji stalowych za pomocą ochronnych systemów malarskich. Pomiar i kryteria przyjęcia grubości suchych powłok na chropowatych powierzchniach.

[23] DIN 55670:1994 Beschichtungsstoffe - Prüfung von Beschichtungen auf Poren und Risse mit Hochspannung (Farby i lakiery - Badanie powłok dla wykrycia porów i pęknięć wysokim napięciem).

[24] EN ISO 4624:2016 Farby i lakiery. Próba odrywania do oceny przyczepności.

[25] EN ISO 16276-1,-2:2007 Ochrona konstrukcji stalowych przed korozją za pomocą ochronnych systemów malarskich. Ocena i kryteria przyjęcia adhezji/kohezji.

[26] NS 476 Farby i powłoki. Kwalifıkacja inspektorów obróbki powierzchniowej. 